\title{
Invited review: Effects of milk ration on solid feed intake, weaning, and performance in dairy heifers
}

\author{
M. A. Khan, D. M. Weary, and M. A. G. von Keyserlingk ${ }^{1}$ \\ Animal Welfare Program, The University of British Columbia, 2357 Main Mall, Vancouver, BC, Canada, V6T $1 Z 4$
}

\section{ABSTRACT}

A feeding regimen that allows a smooth transition from milk to solid feed is vital for successful heiferrearing programs. In the past, research efforts have focused on the development of feeding methods that allow early weaning, perhaps because the risk of disease is highest during the milk feeding stage. To encourage early intake of calf starter, conventional feeding programs have limited the supply of milk (often to $10 \%$ of BW at birth). However, dairy calves provided free access to milk will typically consume more than twice this amount. We critically review the available literature examining the relationship between milk feeding method, solid feed consumption, and rumen development in young dairy calves and identify areas where new work is required. We conclude that milk-fed dairy calves can safely ingest milk at approximately $20 \%$ of body weight $(\mathrm{BW}) / \mathrm{d}$, and greater milk consumption supports greater BW gain, improved feed efficiency, reduced incidence of disease, and greater opportunity to express natural behaviors, which in combination suggest improved welfare. Method of weaning greatly influences feed consumption, rumen development, and growth check in calves provided higher amounts of milk. Gradual weaning encourages starter intake during the preweaning period, and both weaning age and duration of weaning influence this consumption. Increased solid feed consumption during the weaning process contributes to rumen development, permitting higher starter intake and BW gain after weaning. Growth factors in milk may also enhance the growth and maturation of the gastrointestinal tract, but more research is required to understand the role of these factors. Greater nutrient supply through increased amount of milk appears to improve immune function and long-term performance of heifer calves; for example, reducing the age at first breeding and increasing first-lactation milk yield, but more research is needed to confirm these effects.

Received August 17, 2010.

Accepted November 9, 2010.

${ }^{1}$ Corresponding author: marina.vonkeyserlingk@ubc.ca
Key words: dairy heifer, milk, nutrition, health and welfare

\section{INTRODUCTION}

The rumen of the newborn calf is physically underdeveloped and physiologically nonfunctional. Inoculation and establishment of the anaerobic microbial ecosystem, initiation of solid feed intake, and the accompanying fermentation processes and absorption mechanisms are all needed to trigger the development of the rumen. The time course of this development is dependent in large part upon the age of the calf. A smooth transition from liquid feed (milk or milk replacer) to solid feed (grains or forage) is important in minimizing weight loss and distress at weaning (Weary et al., 2009).

Decades of research have focused on developing feeding strategies that facilitate early weaning and transitioning calves from liquid to solid feed (Savage and McCay, 1942; Kertz et al., 1979; Williams and Frost, 1992; Baldwin et al., 2004). These efforts have focused almost exclusively on improving calf starter intakes by reducing the supply of milk fed to calves. One disadvantage of feeding limited amounts of milk is that growth rates are low compared with calves reared by the cow (Flower and Weary, 2001), and low nutrient intake may contribute to the high rates of calf mortality and morbidity that plague the dairy industry (NAHMS, 2007).

Over the past decade several studies have investigated the effects of increasing the supply of milk to young calves (Appleby et al., 2001; Diaz et al., 2001; Jasper and Weary, 2002); these studies have reported higher weight gains and more natural behavior in calves fed more milk. Disadvantages of providing more milk include reduced solid feed intake during the milk-feeding period (Terré et al., 2007; Weary et al., 2008) and slower rumen development (Khan et al., 2007a,b).

To our knowledge, no attempt has been made to summarize the available scientific information on providing higher milk volumes, and no systematic attempt has been made to understand how these higher intakes affect solid feed consumption and weaning in dairy calves. In this review, we first describe how calves feed when reared with the cow and examine how this differs 
from the artificial rearing of the milk-fed calf. Second, we describe the development of starter-based feeding systems for the artificially reared dairy calf. Third, we discuss the relationship between milk intake and solid feed consumption in calves. Last, we summarize research on the effects of milk and solid feed consumption on rumen development, performance, behavior, health, and welfare of dairy calves and identify areas where new research is required.

\section{CALVES REARED BY THE COW}

In situations where domesticated cattle are permitted to rear their calves, mothers express a variety of maternal behaviors toward their young including licking, grooming, nursing, and protecting them from potential predators (von Keyserlingk and Weary, 2007). Cows start licking their calf soon after calving, and the calf normally initiates suckling from the cow within a few hours. One study that measured milk intake of Holstein calves allowed to suckle their dams found that calves consumed approximately $6 \mathrm{~kg} / \mathrm{d}$ in wk 1 and $12 \mathrm{~kg} / \mathrm{d}$ in wk 9 (de Passillé et al., 2008). During the first week of life calves suckle their dam approximately 8 to 12 times daily, with each suckling bout lasting about 10 min (Reinhardt and Reinhardt, 1981). Daily nursing time declines as the calf ages (Nolte et al., 1990), driven largely by a decline in nursing frequency (averaging 4 times a day at 1 mo of age to once daily when calves are 6 mo old; Das et al., 2000).

Calves reared with their dam start grazing and ruminating at approximately 3 wk of age and regularly graze with adult cattle at 4 to 6 mo of age (Key and MacIver, 1980). Young ruminants likely learn to recognize suitable feed sources through mimicking of social companions, most notably the dam (Mirza and Provenza, 1990, 1994). The cow influences the establishment (Key and MacIver, 1980; Mirza and Provenza, 1994) and persistence (Nolte et al., 1990) of the calf's diet and habitat selection.

As the calf matures and it depends less on its dam for milk, the mother's influence wanes (Hinch et al., 1987; Mirza and Provenza, 1994), and peers in the social group have a greater influence on diet (Nolte et al., 1990). In nature, cattle wean their calves when they are approximately 10 mo of age (Reinhardt and Reinhardt, 1981). From the cow's perspective, weaning involves withdrawal of maternal care as the calf becomes socially and nutritionally independent. This is typically a gradual process, with the cow reducing her nursing frequency and milk output over the course of several months. In intensive animal production systems, weaning is often imposed at younger ages and more abruptly than would occur in nature, resulting in distress for both the dam and the calf (Latham and Mason, 2008; Weary et al., 2008). In conclusion, calves fed by the cow consume approximately 6 to $12 \mathrm{~kg} / \mathrm{d}$ of milk via a teat, in several meals per day, and are gradually weaned by the cow over a period of several weeks.

\section{MILK FEEDING PROGRAMS}

\section{Development of Early Weaning and Starter-Based Feeding}

In an early review, Savage and McCay (1942) summarized the work on calf nutrition and management undertaken in the 19th and early 20th centuries, describing the "calf starter method" of raising calves. A key component of this method was that calves were fed small amounts of milk (approximately 10\% BW at birth; Maynard and Norris, 1923). The authors argued that limiting milk intake encouraged intake of calf starter and hay, facilitating weaning at about 7 to 8 wk of age. Beginning in the 1950s a greater emphasis was placed on early weaning programs that encouraged starter consumption by limiting milk supply (Kertz et al., 1979). Forage feeding was discouraged during the milk feeding phase, based on research showing lower starter intake and poorer weight gains in calves provided forage (Warner et al., 1956; Stobo et al., 1966). Other research showed that rumen papillae growth was stimulated by VFA production, in particular butyrate, which was highest in calves consuming larger volumes of starter (Warner et al., 1956; Tamate et al., 1962), suggesting that early exposure to starter may also improve rumen function. As result of this work, low volumes of milk are now typically fed with the aim of increasing starter intake, promoting rumen development, and lowering weaning age.

\section{Enhanced Milk Feeding Systems}

During the last decade several studies have challenged the common practice of providing limited amounts of milk. This work showed poor weight gains (Hammon et al., 2002; Jasper and Weary, 2002), higher risk of disease (Godden et al., 2005; Khan et al., 2007a), and abnormal behaviors (Rushen and de Passillé, 1995; De Paula Vieira et al., 2008) in restricted-fed calves, indicating that this feeding method reduced calf welfare (von Keyserlingk et al., 2009). Providing greater quantities of milk (Jasper and Weary, 2002; Khan et al., 2007a,b) or milk replacer (Diaz et al., 2001; Brown et al., 2005a; Bartlett et al., 2006) improves growth and feed efficiency. Conventional milk replacers contain 20 to $22 \%$ CP (Bartlett et al., 2006; Hill et al., 2008, 2010), but calves benefit most from the increased feeding when 
milk replacers contain higher protein and lower fat (up to $30 \%$ CP with 15 to 20\% fat; Diaz et al., 2001; Cowles et al., 2006; Bascom et al., 2007; Hill et al., 2010). Increased lean tissue growth has been observed in calves fed milk replacer with increasing protein contents when energy was not limiting (Diaz et al., 2001; Tikofsky et al., 2001).

This milk feeding approach has been described using a variety of terms, including accelerated early nutrition, accelerated growth, enhanced nutrition, intensified nutrition, and biologically appropriate growth (see review by Drackley, 2008). This new research resonates with much older literature showing the benefits of providing calves more milk. For example, reports from the early 1800s claimed that calves at the "best" Swiss dairies were fed whole milk liberally (about $8 \mathrm{~kg}$ of milk daily) and gained approximately $0.9 \mathrm{~kg}$ per day (Boussingault, 1845).

\section{MILK AND SOLID FEED INTAKE}

\section{Control of Milk Intake}

Milk constituents (fat, lactose, and protein) are digested by abomasal enzymes (rennin, pepsin, pregastric lipase) and later in the intestine (pancreatic lipase, trypsin, chymotrypsin, carboxypeptidase, elastase, lactase; Drackley, 2008). This gastric and intestinal digestion provides small- and medium-chain fatty acids, glucose, galactose, and amino acids to the calf for the maintenance of vital body functions and growth. In the young calf, glucose and fatty acids are the main energy sources; thus, glucostatic or lipostatic metabolic control may be important in regulating milk consumption and meal size, at least before the initiation of solid feed consumption. Low blood glucose levels trigger the onset of hunger, whereas an increase in glycemia signals satiety and the termination of eating (Williams and Frost, 1992). Curd formation may also play an important role in controlling milk intake because of mechano-receptors present in the abomasum (Forbes, 1995). Furthermore, in the young dairy calf, emptying of the abomasum depends on the chemical composition of chyme (Williams and Frost, 1992). Osmoreceptors and acid chemoreceptors are distributed along the length of intestine, and these receptors likely also play a role in initiating a chain of feedback mechanisms that control abomasal emptying and thus intake (Forbes, 1971, 1995). Gut peptides (gastrin, secretin, somatostatin, cholecystokinin, vasoactive intestinal polypeptide, pancreatic polypeptide, gastric inhibitory polypeptide, motilin) are also important in signaling satiety to regulate milk consumption in young ruminants (for details, see Guilloteau et al., 1997). Taste and learned cues associated with preferred flavors are also linked to hunger (e.g., the taste of lactose increases the motivation of dairy calves to drink milk; de Passillé and Rushen, 2006).

When offered milk ad libitum, calves typically consume about $20 \% \mathrm{BW} / \mathrm{d}$, equivalent to approximately 10 to $12 \mathrm{~L}$ of whole milk for Holstein calves (Jasper and Weary, 2002; Khan et al., 2007a; Sweeney et al., 2010). Calves fed limited volumes of milk also show behaviors indicative of chronic hunger (Thomas et al., 2001; Jensen and Holm, 2003; De Paula Vieira et al., 2008). Calves provided $5 \mathrm{~L} / \mathrm{d}$ of milk vocalized at higher rates compared with calves fed $8 \mathrm{~L} / \mathrm{d}(31.4 \pm 7.0$ vs. $5.0 \pm 3.4$ calls daily; Thomas et al., 2001). Thomas et al. (2001) also reported higher pitch calls in calves fed $5 \mathrm{~L} / \mathrm{d}(120.6 \pm 2.2$ vs. $109.0 \pm 3.1 \mathrm{~Hz}$ fundamental frequency). Calves fed by automatic milk feeding systems (Jensen and Holm, 2003; Jensen, 2006; Nielsen et al., 2008; De Paula Vieira et al., 2008) make several times more unrewarded visits to the feeder (i.e., visit the feeder when they are not entitled to milk, reducing the efficiency of the feeder) when fed more restricted amounts of milk (Figure 1). Restricting milk rations also appears to reduce play behavior in calves; Krachun et al. (2010) reported that calves fed $6 \mathrm{~L} / \mathrm{d}$ ran (one indicator of play behavior) far less than those fed 12 $\mathrm{L} / \mathrm{d}$.

Bucket-fed calves provided a restricted amount of milk ( $\sim 2 \mathrm{~kg}$ twice daily) finish their milk meal in approximately 45 s (Appleby et al., 2001). In contrast, calves nursing their dam have several sucking bouts per day, each one lasting about $10 \mathrm{~min}$ (de Passillé, 2001). Feeding calves milk ad libitum through a teat allows the calf to express similar behavior in terms of the frequency and duration of milk meals (Appleby et al., 2001); teat access can slow intakes, improve milk digestion, and reduce cross-sucking (de Passillé, 2001). Senn et al. (2000) found a positive correlation between milk intake and postprandial interval. These authors suggested that calves have postingestion factors (e.g., curd formation in abomasum and serum insulin) involved in postprandial satiety, whereby young calves can regulate milk intake based on time and volume of their last meal.

\section{Relationship Between Milk and Solid Feed Intake}

Calves start consuming measurable amounts of solid feed at about $14 \mathrm{~d}$ of age (Williams and Frost, 1992; Khan et al., 2008), and intake increases rapidly when milk rations are reduced (Khan et al., 2007a,b) or milk is withdrawn (Jasper and Weary, 2002). An inverse relationship between milk and solid feed intake has been demonstrated in older (Kertz et al., 1979) and more recent work (Terré et al., 2007; Raeth-Knight et al., 


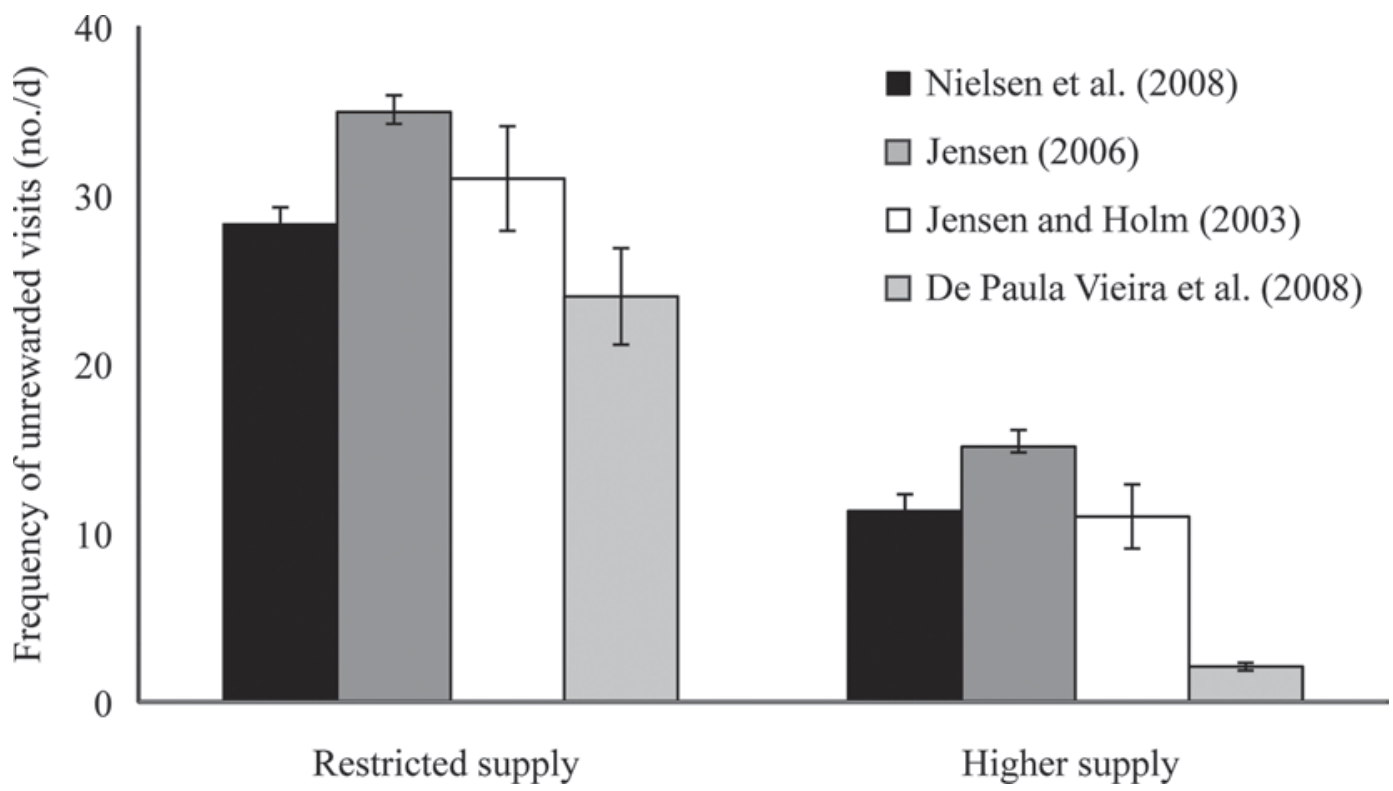

Figure 1. Mean $( \pm \mathrm{SE})$ daily frequency of unrewarded visits to automatic milk feeder by calves fed restricted ( 8 to $12 \%$ of BW) and higher amount $(>4.5 \mathrm{~L} / \mathrm{d}$ ) or ad libitum supply of milk (adopted from Jensen and Holm, 2003; Jensen, 2006; De Paula Vieira et al., 2008; Nielsen et al., 2008).

2009). Calves fed milk or milk replacer equivalent to $10 \%$ of BW typically consume almost twice as much starter as calves fed higher amounts in the weeks before weaning (Jasper and Weary, 2002; Cowles et al., 2006; Raeth-Knight et al., 2009). This reduced intake of solid feed among calves fed more milk is not surprising; these calves likely feel less hungry because of increased satiety associated with the chemical (higher blood glucose and insulin) and mechanical factors (continuous gut-filling because of curd formation) described above. However, even when unlimited amounts of milk are offered to young ruminants, they begin to chew solid food at about 2 wk of age and indeed appear to crave it when it is not available (Forbes, 1971). Diaz et al. (2001) reported that in the absence of solid feed, calves consumed bedding material, suggesting a growing hunger for solids as calves age.

After weaning, voluntary feed intake in calves is governed by the calves' digestive capacity (rumen volume, feed fermentation patterns, absorption and metabolic activities of rumen epithelium, rumen motility and digesta flow), physio-chemical attributes of solid feed (carbohydrate nature, feed processing; protein level and quality; feed particle size and length) and changes in post-absorptive metabolites (Lesmeister and Heinrichs, 2004; Khan et al., 2007b, 2008; Porter et al., 2007). Feeding larger amounts of milk before weaning may delay physical and metabolic rumen development depressing the solid feed consumption around weaning (Hill et al., 2010; Sweeney et al., 2010).

\section{RUMEN DEVELOPMENT}

Calves rely on the nutrients obtained from milk during the first few weeks of life. Inoculation and establishment of the anaerobic ruminal microbial ecosystem, initiation of starter feed consumption, and fermentation processes and absorption mechanisms are needed to trigger rumen development (Williams and Frost, 1992; Baldwin et al., 2004). Changes must also occur at the hepatic and intestinal levels to allow calves to make use of fermentation end-products for maintenance and growth (see reviews by Baldwin et al., 2004; Drackley, 2008).

Restricted milk feeding encourages solid feed consumption and has been viewed as a key contributor to the metabolic and physical development of the rumen (Baldwin et al., 2004). Volatile fatty acids produced from the fermentation of ingested solids stimulate the development of ruminal papillae in young calves (Sander et al., 1959), and feed bulk contributes to the muscular development and expansion of ruminal volume (Stobo et al., 1966). Grain-based starters that promote production of VFA, such as butyrate, have been viewed as the feed type of choice for triggering papillae growth in the rumen wall (Tamate et al., 1962; Stobo et al., 1966).

Given these benefits of high starter intakes, some have questioned the wisdom of providing calves higher milk volumes that can decrease solid feed consumption (Quigley et al., 2006; Hill et al., 2010). Little work has specifically addressed differences in ruminal morphol- 


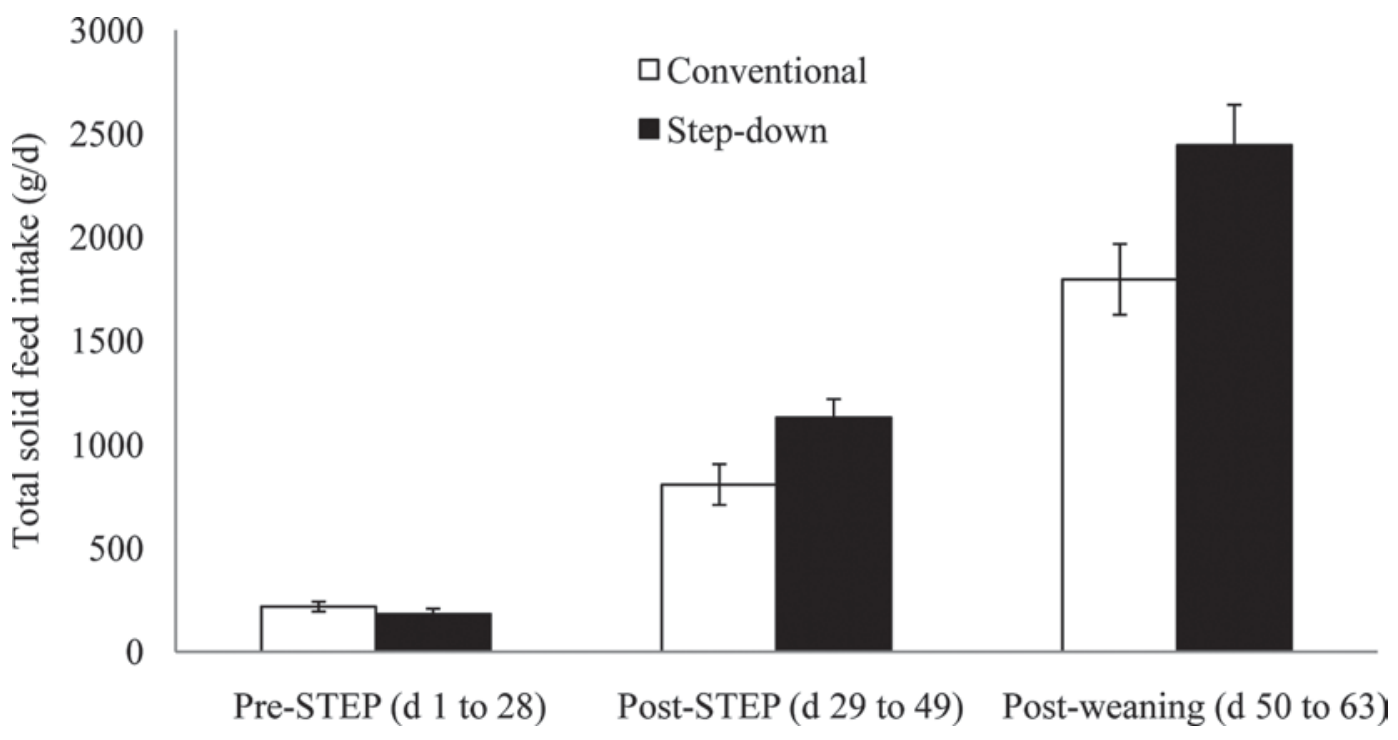

Figure 2. Mean $( \pm \mathrm{SE})$ solid feed (starter plus hay) consumption by Holstein calves fed milk through step-down or conventional methods (adopted from Khan et al., 2007b). In the conventional method, the calves were fed milk at $10 \%$ of BW until $44 \mathrm{~d}$ of age. In the step-down method, the calves were given milk until $23 \mathrm{~d}$ of age at $20 \%$ of BW (prestep), which was gradually reduced (between $\mathrm{d} 24$ and 28 ) to $10 \%$ of BW for the remaining $16 \mathrm{~d}$ of the weaning period (poststep). Calves in both the conventional and step-down treatments were weaned gradually by diluting milk with water between 45 and $49 \mathrm{~d}$ of age.

ogy in relation to milk intake. Kristensen et al. (2007) fed a barley-based starter concentrate with varying amounts of milk to calves and showed that calves supplied a daily allotment of 3.1 versus $8.3 \mathrm{~L}$ of milk had heavier forestomachs (as \% of BW), but found that, regardless of milk allowance, the ruminal environment of young calves was characterized by a low ruminal $\mathrm{pH}$ and high VFA concentration. These authors attributed the heavier forestomachs in the restricted-fed calves to greater solid feed consumption compared with the calves receiving more milk. Roth et al. (2009) found that the length of papillae in the atrium or ventral ruminal sac was not affected by milk allowance or by the resulting variation in solid feed consumption in calves.

Khan et al. (2007b) found that providing calves a large amounts of milk early in life and then reducing intakes before weaning (step-down method) caused a surge in solid feed consumption (Figure 2). They also reported a metabolically more developed and heavier forestomach in calves fed milk through the step-down method compared with those fed restricted quantities of milk. Roth et al. (2009) reported similar starter intakes and rumen development in calves weaned using concentrate-dependent (milk supply was reduced once calves consumed $2 \mathrm{~kg} / \mathrm{d}$ of starter for 4 consecutive days) or conventional weaning methods (abruptly removing all milk at $12 \mathrm{wk}$ of age). The lack of treatment differences in the latter study may be explained by the relatively low amount of milk offered to calves on both treatments $(6 \mathrm{~L} / \mathrm{d})$ and the late weaning age.
Ruminal development in calves is likely affected by more than just butyrate (Baldwin et al., 2004). A greater supply of energy and nutrients from higher milk intake could contribute directly to the development of rumen papillae through metabolic axis (Shen et al., 2004). Changes in endocrine factors (insulin and IGF-I) in relation to higher milk intake may also promote the development of the ruminal epithelium (Gerrits et al., 1998; Shen et al., 2004). Growth factors in colostrum and milk may also enhance the growth and maturation of the gastrointestinal tract (Blum and Baumrucker, 2002; Blum, 2006), but more research is required to understand the role of these factors in rumen development.

\section{PERFORMANCE AND HEALTH}

\section{Preweaning}

During the last decade several studies have investigated the effects of feeding high volumes of milk on calf growth (Table 1; Diaz et al., 2001; Flower and Weary, 2001; Jasper and Weary, 2002; Brown et al., 2005a; Bartlett et al., 2006; Khan et al., 2007a,b; Jasper et al., 2008; Borderas et al., 2009; Sweeney et al., 2010). Calves provided access to higher volumes of milk early in life can double their nutrient intake compared with those fed amounts equivalent to approximately $10 \%$ of BW, and these calves are able to gain more weight $(\sim 1$ $\mathrm{kg} / \mathrm{d})$ compared with restricted-fed counterparts $(\sim 0.45$ 
$\mathrm{kg} / \mathrm{d}$ ) during the preweaning period. Higher milk intakes also result in improved feed conversion efficiencies during the preweaning period (Diaz et al., 2001; Khan et al., 2007a), as young animals preferentially make use of available nutrients to maintain vital body functions and only those nutrients in excess of what is required for maintenance can be used for tissue gain and skeletal growth (NRC, 2001).

The daily nutrients requirements for maintenance vary with $\mathrm{BW}$ and rate of $\mathrm{BW}$ gain in calves. Under thermoneutral conditions ( 15 to $25^{\circ} \mathrm{C}$ ambient temperature; Drackley, 2005), the young calves are equipped with regulatory mechanisms to maintain their core body temperature $\left(38.5^{\circ} \mathrm{C}\right.$; NRC, 2001). A calf weighing 45 $\mathrm{kg}$ requires $1.75 \mathrm{Mcal} / \mathrm{d}$ of $\mathrm{ME}$ for maintenance when reared under thermoneutral conditions (NRC, 2001). Whole milk contains about $5.4 \mathrm{Mcal}$ of $\mathrm{ME} / \mathrm{kg}$ of solids; thus, a calf ( $45 \mathrm{~kg}$ of BW) requires daily $325 \mathrm{~g}$ of milk solids or $2.6 \mathrm{~kg}$ of whole milk just for maintenance (Drackley, 2008). It is important to note that most commercial milk replacers contain a lower concentration of fat than whole milk and therefore provides lower $\mathrm{ME}$ if fed at similar rates. As the temperature falls below the lower critical temperature $\left(8\right.$ to $\left.10^{\circ} \mathrm{C}\right)$, a calf needs more dietary energy to maintain body temperature (NRC, 2001). If calves are fed the same amount of milk as under moderate environmental conditions, less energy will be available to support growth. Under very hot conditions, calves may also require additional energy to cope with the challenges associated with heat

Table 1. Effects of feeding higher volumes ${ }^{1}$ of liquid feed than conventional amounts to Holstein calves on their production, health, and behavioral parameters

\begin{tabular}{|c|c|c|}
\hline Parameter & Effect $^{2}$ & References \\
\hline \multicolumn{2}{|l|}{ Preweaning performance } & \multirow{6}{*}{$\begin{array}{l}\text { Diaz et al., 2001; Jasper and Weary, 2002; Brown et al., 2005a; } \\
\text { Bartlett et al., 2006; Cowles et al., 2006; Khan et al., 2007a,b; Terré et } \\
\text { al., 2007; Borderas et al., 2009; Hill et al., 2010; Sweeney et al., } 2010\end{array}$} \\
\hline Total nutrient supply ${ }^{3}$ & + & \\
\hline Starter intake & - & \\
\hline BW gain & + & \\
\hline Structural growth ${ }^{4}$ & + & \\
\hline \multicolumn{2}{|l|}{$\begin{array}{l}\text { Feed efficiency } \\
\text { Postweaning performance }\end{array}$} & \\
\hline Digestible nutrients intake & $-/+^{*}$ & \multirow{4}{*}{$\begin{array}{l}\text { Jasper and Weary, 2002; Khan et al., 2007a,b; Terré et } \\
\text { al., 2007; Roth et al., 2008; Borderas et al., 2009; Raeth- } \\
\text { Knight et al., 2009; Hill et al., 2010; Sweeney et al., } 2010\end{array}$} \\
\hline BW gain & $-1+^{*}$ & \\
\hline Structural growth ${ }^{4}$ & $+^{*}$ & \\
\hline Feed efficiency & $-1+^{*}$ & \\
\hline \multicolumn{2}{|l|}{ Long-term performance } & \multirow{2}{*}{$\begin{array}{l}\text { Shamay et al., 2005; Raeth-Knight et al., 2009; Brown et } \\
\text { al., 2005b; Meyer et al., 2006; Moallem et al., } 2010\end{array}$} \\
\hline Mammary development ${ }^{6}$ & + & \\
\hline Rumen development $^{8}$ & $-/+^{*}$ & \multirow{5}{*}{$\begin{array}{l}\text { Diaz et al., 2001; Nonnecke et al., 2003; Godden et } \\
\text { al., 2005; Bartlett et al., 2006; Quigley et al., 2006; } \\
\text { Khan et al., 2007a,b; Borderas et al., 2009 } \\
\text { Kristensen et al., 2007; Khan et al., 2007b; Roth et al., 2008, } 2009 \\
\text { Gerrits et al., 1998; Kühne et al., 2000; Hammon et al., 2002; } \\
\text { Smith et al., 2002; Shen et al., 2004; Khan et al., 2007a,b }\end{array}$} \\
\hline Blood metabolites & & \\
\hline Glucose & $-/+^{*}$ & \\
\hline BHBA & $-1+*$ & \\
\hline IGF & + & \\
\hline \multicolumn{3}{|l|}{ Behavioral parameters } \\
\hline Meal time (liquid feed) & + & \multirow{5}{*}{$\begin{array}{l}\text { Thomas et al., 2001; De Paula Vieira et al., 2008; Jasper } \\
\text { et al., 2008; Nielsen et al., 2008; Krachun et al., } 2010\end{array}$} \\
\hline Lying time (resting) & + & \\
\hline Vocalization & - & \\
\hline Cross suckling & -* & \\
\hline Running duration (play behavior) & + & \\
\hline
\end{tabular}

${ }^{1}$ Supply of milk (whole milk, waste milk, and pasteurized milk) or milk replacers of varying composition to calves (individual and group housed) more than conventional amounts (10\% of calf BW) for 4 to 8 wk of age using nipples, buckets, and automatic feeders.

${ }^{2}$ Effects: $+=$ increased in calves fed higher volumes of liquid feed than conventional amount; $-=$ decreased in calves fed higher volumes of liquid feed than conventional amount; ${ }^{*}(+$ or -$)=$ response with gradual weaning in calves fed higher volumes of liquid feed.

${ }^{3}$ Nutrients supplied by both solid and liquid feeds.

${ }^{4}$ Structural growth $=$ increase in hip or wither height, heart girth, and hip width.

${ }^{5}$ Total nutrients supplied by starter and hay diet.

${ }^{6}$ Mammary development is measured as mammary cell proliferation and (or) increase in mammary DNA mass.

${ }^{7}$ Different studies used different methods for fecal scoring.

${ }^{8}$ Rumen development includes metabolic development and papillae growth. 
stress (e.g., increased panting and respiratory rates), but no study to date has assessed the energetic costs associated with heat stress in young dairy calves.

Calves fed $4 \mathrm{~L} / \mathrm{d}$ of milk are not able to consume enough starter (at least for the first $2 \mathrm{mo}$ ) to match the nutrient intakes of calves fed milk ad libitum or to meet their nutrient requirements for growth and development (Jasper and Weary, 2002; Sweeney et al., 2010). Young calves fed restricted amounts of milk are unable to meet their daily energy requirement through milk and starter intake, even though these calves typically consume twice the amount of starter as calves provided a high milk allowance (Nielsen et al., 2008).

High rates of mortality of animals during the milk feeding period are almost always associated with poor welfare (von Keyserlingk et al., 2009). The recent NAHMS (2007) survey reports that many farms experience high levels of mortality, with pre-weaning averaging approximately $8 \%$. Calves are particularly susceptible to disease during the milk-feeding period, especially respiratory diseases and diarrhea (Svensson et al., 2003). Some researchers (Khouri and Pickering, 1968; Diaz et al., 2001; Quigley et al., 2006) have reported a higher occurrence of diarrhea in calves supplied higher levels of milk or milk replacers compared with restricted fed calves, but other studies report no difference (Mylrea, 1966; Jasper and Weary, 2002; Khan et al., 2007a). This discrepancy in results may partly be attributed to differences in fecal scoring systems (Borderas et al., 2009), variation in colostrum feeding practices, amount, method and quality of liquid feed (milk or milk replacer) supplied, and differences in climatic and management situations across studies. We suggest that a high incidence of diarrhea is more related to poor sanitary, management, and housing conditions than to level of milk intake (Hammon et al., 2002; Jasper and Weary, 2002).

Nutritional deficiency can depress immune function and thus increase susceptibility to diseases in calves (Nonnecke et al., 2003). Godden et al. (2005) fed equal volumes of pasteurized milk and a conventional milk replacer to calves during summer and winter, but differences in composition of the 2 liquid feeds meant that calves receiving milk ingested about $17 \%$ more energy. Mortality was similar in the 2 treatments during the summer, but was much greater for calves fed milk replacer $(21.0 \%)$ than for those fed milk (2.8\%) during cold weather. This difference can likely be attributed to the marginal nutrient status of the calves fed milk replacer, combined with higher maintenance requirements during periods of cold stress (see review by Drackley, 2008).

Nutrition is a critical determinant of immune responses, with the protein and energy supply influ- encing cell-mediated immunity, cytokine production, the complement system, phagocytic functions, and secretory IgA antibody concentrations (Galyean et al., 1999). Smith et al. (2002) found that increased nutrient intake sufficient to optimize growth performance was associated with elevated plasma IGF-I, insulin, and glucose concentrations. Their data also demonstrated that in well-nourished calves, the somatotropic axis is functionally coordinated with nutrient intake and growth hormone. Because the somatotropic axis influences developmental and functional aspects of the immune system (Kooijman et al., 1996), greater milk consumption may benefit the immune system in calves. However, Nonnecke et al. (2003) found small or no difference in functional aspects of components of the immune system in calves fed different amounts of milk or milk replacers. In summary, better health in calves fed more milk is likely due to improved supply of nutrients rather than to any specific alteration in the immune system.

\section{Postweaning}

Postweaning growth of calves is dependent upon the ability to accommodate and digest solid feed. Despite the advantages of increased milk supply on tissue gain and skeleton growth during the preweaning period, the practice is less attractive if it depresses consumption of solid feed after weaning. High milk intakes before weaning can depress solid feed intakes after weaning if milk feeding is ended abruptly (Terré et al., 2007; Weary et al., 2008). Reduced weight gain and even weight loss at weaning have been attributed to poor rumen development (both volume and metabolic capacity) in calves fed milk ad libitum (Khan et al., 2007b; Sweeney et al., 2010). Reductions in BW may be due in part to the emptying of the gastrointestinal tract (rather than loss of body tissue), but it is unlikely that this can account for the entire effect (Sweeney et al., 2010). Terré et al. (2007) reported greater apparent DM digestibility around weaning (6 wk of age) in calves fed lower amounts of milk replacer compared with those fed higher amounts of milk replacer and attributed this to early initiation of starter intake in the former. Similarly, Hill et al. (2010) reported results from 2 experiments showing that calves fed more milk replacer before weaning had lower DM digestibility of calf starter after weaning. In the first experiment the milk replacer treatment was confounded by differences in starter composition, but the second experiment was not confounded and still reported a $7 \%$ decrease in apparent postweaning starter digestibility in calves fed the high-milk-replacer ration, likely associated with lower starter intakes before weaning. 
The method of weaning greatly influences the lower growth rates observed in calves provided higher amounts of milk during the preweaning period. Abrupt weaning in restricted-fed and ad libitum-fed calves results in a greater depression in growth than does gradual weaning (Roth et al., 2008; Weary et al., 2008). In contrast, gradual weaning methods that encourage the consumption of solid feed during the preweaning period reduce the lag between demand and supply of nutrients after weaning, minimizing or preventing depressed growth (Khan et al., 2007a,b; Sweeney et al., 2010). Calves on a step-down milk feeding regimen (Khan et al., 2007b) eat more solid feed before and after weaning (Figure 2) and maintain their growth advantage over calves fed restricted quantities of milk after weaning. Khan et al. (2007b) attributed the improved performance of the step-down calves to a greater rumen capacity that allowed for higher intake of solid feed. Work by Nielsen et al. (2008) and Jasper et al. (2008) provides further evidence in that calves gradually weaned from high milk diets were able to maintain or even increase energy intake during the first week after weaning versus those abruptly weaned. Age at weaning is also important; Sweeney et al. (2010) reported that calves gradually weaned starting at $19 \mathrm{~d}$ of age were unable to compensate for the reduced nutrients from milk by increasing their intake of starter; calves weaned at older ages were better able to compensate for reduced milk intake.

Solid feed consumption before weaning can also be improved through social facilitation and by improving the presentation and palatability of solid feed (Weary et al., 2008). Chua et al. (2002) reported that grouphoused calves showed less growth check at weaning than did individually housed calves. A more recent study (De Paula Vieira et al., 2010) found that pair-housed calves ingested more starter during the preweaning period than did individually housed calves; they attributed this increase to social facilitation. Young ruminants likely learn to identify appropriate sources of solid food through allelomimicry, using the dam or peers as models (Mirza and Provenza, 1990). Carbohydrate and protein sources, feed processing methods (biological, chemical, mechanical, or thermal), physical form of diet (textured or pelleted), and additives (direct-fed microbial, enzymes, and feed flavors) could affect the palatability of the starter feed (Lesmeister and Heinrichs, 2004; Khan et al., 2008).

The literature reviewed above illustrates that gradually reducing milk intake is an effective method of increasing starter consumption before weaning, but only if calves are more than 3 wk old. Older calves increase their intake of solids even if the milk rations are not decreased; age-dependent increases in starter intake are more pronounced when calves are fed limited quantities of milk, making step-down programs especially valuable for calves on high milk rations.

\section{Longer Term Effects}

Several studies have examined the effects of varying the amount of milk fed on long-term productivity of heifers (Drackley, 2005). Higher rates of growth observed early in life are associated with reduced breeding age (Raeth-Knight et al., 2009) and higher milk yield when the calf matures (Moallem et al., 2010). Soberon et al. (2009) analyzed the preweaning growth rate of heifers ( $\mathrm{n}=792$; ADG 0.13 to $1.3 \mathrm{~kg}$ ). Preweaning ADG had the greatest correlation with first-lactation milk production. Approximately $25 \%$ of the variation in first-lactation milk production could be explained by preweaning average daily BW gain; for every 0.1 $\mathrm{kg}$ increase in preweaning average daily gain, heifers produced $107 \mathrm{~kg}$ more milk during their first lactation. This evidence suggests that the provision of more nutrients early in life can improve milk yields.

Some critics of feeding higher amounts of milk have suggested that these diets could have detrimental effects on mammary development (Lammers et al., 1999; Radcliff et al., 2000), although little evidence exists to justify this concern (Sejrsen et al., 2000). Indeed, mammary cell growth increases with preweaning nutrient intake: mammary DNA mass increased by 32 to $47 \%$ (Brown et al., 2005b) and mammary cell proliferation increased by $40 \%$ (Meyer et al., 2006) in heifers fed high milk volumes compared with those that were limit fed. These results may help account for the higher milk production of calves fed more milk, but more research is needed to understand the mechanisms by which milk intake affects future milk yield.

Moallem et al. (2010) compared heifers fed either whole milk or milk replacer, both with ad libitum access for 30 min twice daily. Heifers provided the whole milk were $23 \mathrm{~d}$ younger at their first insemination compared with those fed milk replacer. Moallem et al. (2010) attributed this finding to higher preweaning growth that was maintained after weaning and throughout the subsequent growing period by the milk-fed heifers over the heifers fed milk replacer. Heifers fed ad libitum amounts of whole milk also produced $10 \%$ more milk in their first lactation compared with those fed milk replacer. The improvements in milk production observed in heifers provided whole milk early in life might be related to the greater growth or to physiological effects of whole milk on mammary development (Meyer et al., 2006). The discussion surrounding the provision of milk on performance has, for the most part, not differentiated 
between whole milk and milk replacers, but differences highlighted by Moallem et al. (2010) suggest that more work in this area is warranted.

\section{IMPLICATIONS}

The literature reviewed above collectively indicates that conventional feeding practices (i.e., limiting milk intake to approximately $4 \mathrm{~L} / \mathrm{d}$ or $0.5 \mathrm{~kg}$ of solids) leave calves hungry and compromise growth, health, welfare, and future milk production. However, higher milk rations can negatively affect solid food intake before weaning, reducing feed consumption and increasing growth check in the days after calves are weaned. If poorly managed, this growth check can negate many of the advantages of improved early nutrition described above. Together, these lines of evidence suggest that the optimal milk ration is greater than that used in conventional practice, but less than ad libitum intake.

One perspective on this issue is to again look at calves reared with their dam. The cow plays a major role in controlling the duration and frequency of each suckling event, and thus total daily intake (von Keyserlingk and Weary, 2007). During the first few weeks after birth the cow initiates the majority of the nursing episodes, but as the calf ages it initiates more nursing events (Lidfors et al., 1994) and the cow becomes less willing to nurse and more likely to terminate the nursings that do occur (Nolte et al., 1990; Das et al., 2000). Not surprisingly, the number of bouts is most frequent during the first few weeks of lactation. Artificial rearing systems available to date do not account for this maternal influence in controlling milk intake, particularly in the first few weeks of life. In some of the early work comparing limitfed to ad libitum-fed calves the variation in daily milk intake was much higher in the ad libitum-fed calves (see Appleby et al., 2001; Jasper and Weary, 2002). We speculate that this increased variation may arise from the lack of maternal input in regulating milk intake when ad libitum volumes are available. Automatic calf feeders could be programmed to regulate intakes using feedback from the calf (e.g., butting, drinking rate, or number of nonnutritive visits); we encourage further research on this topic.

The results reviewed above suggest that growth factors in milk may enhance the growth and maturation of the gastrointestinal tract, but more research is required to understand the role of these factors. Greater nutrient supply through milk appears to improve immune function and long-term performance of heifer calves; for example, reducing the age at first breeding and increasing first-lactation milk yield, but more research data are also needed to confirm these effects. Existing rec- ommendations on solid feeds (starter and forage) and feeding methods are derived from studies on restrictedfed calves. We suggest that the effects of different types of solid feeds should now be evaluated on calves fed higher amounts of milk.

Restricted milk intakes encourage solid feed consumption and thus the physiological and metabolic development of the rumen, but these effects become important only after about 3 wk of age when calves are better able to digest calf starter. Younger calves benefit from increased milk rations by being able to express more natural feeding behavior, reduced signs of hunger, improved growth and likely improved health. Maintaining these early benefits using appropriate weaning methods and postweaning management can also improve longer term growth and productivity, and ultimately benefit the welfare of the growing heifer.

\section{ACKNOWLEDGMENTS}

The Animal Welfare Program is funded by Canada's Natural Sciences and Engineering Research Council (Ottawa, ON, Canada) Industrial Research Chair Program with industry contributions from the Dairy Farmers of Canada (Ottawa, ON, Canada), Westgen Endowment Fund (Milner, BC, Canada), Pfizer Animal Health (Kirkland, QC, Canada), BC Cattle Industry Development Fund (Kamloops, BC, Canada), the BC Milk Producers (Burnaby, BC, Canada), BC Dairy Foundation (Burnaby, BC, Canada), BC Dairy Industry Research and Education Fund (Abbotsford, BC, Canada), and Alberta Milk (Edmonton, AB, Canada).

\section{REFERENCES}

Appleby, M. C., D. M. Weary, and B. Chua. 2001. Performance and feeding behavior of calves on ad libitum milk from artificial teats. Appl. Anim. Behav. Sci. 74:191-201.

Baldwin, R. L. VI, K. R. McLeod, J. L. Klotz, and R. N. Heitmann. 2004. Rumen development, intestinal growth and hepatic metabolism in the pre- and postweaning ruminant. J. Dairy Sci. 87(E. Suppl.):E55-E65.

Bartlett, K. S., F. K. McKeith, M. J. VandeHaar, G. E. Dahl, and J. K. Drackley. 2006. Growth and body composition of dairy calves fed milk replacers containing different amounts of protein at two feeding rates. J. Anim. Sci. 84:1454-1467.

Bascom, S. A., R. E. James, M. L. McGilliard, and M. E. Van Amburgh. 2007. Influence of dietary fat and protein on body composition of Jersey bull calves. J. Dairy Sci. 90:5600-5609.

Blum, J. W. 2006. Nutritional physiology of neonatal calves. J. Anim. Physiol. Anim. Nutr. (Berl.) 90:1-11.

Blum, J. W., and C. R. Baumrucker. 2002. Colostral and milk insulinlike growth factors and related substances: Mammary gland and neonatal (intestinal and systemic) targets. Domest. Anim. Endocrinol. 23:101-110.

Borderas, T. F., A. M. B. de Passillé, and J. Rushen. 2009. Feeding behavior of calves fed small or large amounts of milk. J. Dairy Sci. $92: 2843-2852$.

Boussingault, J. B. 1845. Rural Economy. G. Law, transl. Orange Judd, New York, NY. 
Brown, E. G., M. J. Vandehaar, K. M. Daniels, J. S. Liesman, L. T. Chapin, J. W. Forrest, R. M. Akers, R. E. Pearson, and M. S. Weber Nielsen. 2005b. Effect of increasing energy and protein intake on mammary development in heifer calves. J. Dairy Sci. $88: 595-603$.

Brown, E. G., M. J. Vandehaar, K. M. Daniels, J. S. Liesman, L. T. Chapin, D. H. Heisler, and M. S. Weber Nielsen. 2005a. Effects of increasing energy and protein intake on body growth and carcass composition of heifer calves. J. Dairy Sci. 88:585-594.

Chua, B., E. Coenen, J. van Delen, and D. M. Weary. 2002. Effects of pair versus individual housing on the behavior and performance of dairy calves. J. Dairy Sci. 85:360-364.

Cowles, K. E., R. A. White, N. L. Whitehouse, and P. S. Erickson. 2006. Growth characteristics of calves fed an intensified milk replacer regimen with additional lactoferrin. J. Dairy Sci. 89:48354845.

Das, S. M., I. Redbo, and H. Wiktorsson. 2000. Effect of age of calf on suckling behaviour and other behavioural activities of Zebu and crossbred calves during restricted suckling periods. Appl. Anim. Behav. Sci. 67:47-57.

de Passillé, A. M. B. 2001. Sucking motivation and related problems in calves. Appl. Anim. Behav. Sci. 72:175-187.

de Passillé, A. M. B., and J. Rushen. 2006. Calves' behaviour during nursing is affected by feeding motivation and milk availability. Appl. Anim. Behav. Sci. 101:264-275.

de Passillé, A. M. B. P., G. Marnet, H. Lapierre, and J. Rushen. 2008. Effects of twice-daily nursing on milk ejection and milk yield during nursing and milking in dairy cows. J. Dairy Sci. 91:1416-1422.

De Paula Vieira, A., V. Guesdon, A. M. de Passillé, M. A. G. von Keyserlingk, and D. M. Weary. 2008. Behavioural indicators of hunger in dairy calves. Appl. Anim. Behav. Sci. 109:180-189.

De Paula Vieira, A., M. A. G. von Keyserlingk, and D. M. Weary 2010. Effects of pair versus single housing on performance and behavior of dairy calves before and after weaning from milk. J. Dairy Sci. 93:3079-3085.

Diaz, M. C., M. E. Van Amburgh, J. M. Smith, J. M. Kelsey, and E. L. Hutten. 2001. Composition of growth of Holstein calves fed milk replacer from birth to 105-kilogram body weight. J. Dairy Sci. 84:830-842.

Drackley, J. K. 2005. Early growth effects on subsequent health and performance of dairy heifers. Chapter 12 in Calf and Heifer Rearing. P. C. Garnsworthy, ed. Nottingham University Press, Nottingham, UK.

Drackley, J. K. 2008. Calf nutrition from birth to breeding. Vet. Clin. North Am. Food Anim. Pract. 24:55-86.

Flower, F. C., and D. M. Weary. 2001. Effects of early separation on the dairy cow and calf: 2 . Separation at 1 day and 2 weeks after birth. Appl. Anim. Behav. Sci. 70:275-284.

Forbes, J. M. 1971. Physiological changes affecting voluntary food intake in ruminants. Proc. Nutr. Soc. 30:135-142.

Forbes, J. M. 1995. Voluntary Food Intake and Diet Selection in Farm Animals. CAB International, Wallingford, UK

Galyean, M. L., L. J. Perino, and G. C. Duff. 1999. Interaction of cattle health/immunity and nutrition. J. Anim. Sci. 77:1120-1134.

Gerrits, W. J. J., E. Decuypere, M. W. A. Verstegen, and V. Karabinas. 1998. Effect of protein-free energy intake on plasma concentrations of insulin-like growth factor I and thyroid hormones in preruminant veal calves. J. Anim. Sci. 76:1356-1363.

Godden, S. M., J. P. Fetrow, J. M. Feirtag, L. R. Green, and S. J. Wells. 2005. Economic analysis of feeding pasteurized nonsaleable milk versus conventional milk replacer to dairy calves. J. Am. Vet. Med. Assoc. 226:1547-1554.

Guilloteau, P., I. Le Huërou-Luron, J. A. Chayvialle, R. Toullec, R. Zabielski, and J. W. Blum. 1997. Gut regulatory peptides in young cattle and sheep. Zentralbl. Veterinarmed. A 44:1-23.

Hammon, H. M., G. Schiessler, A. Nussbaum, and J. W. Blu m. 2002. Feed intake patterns, growth performance, and metabolic and endocrine traits in calves fed unlimited amounts of colostrum and milk by automate, starting in the neonatal period. J. Dairy Sci. 85:3352-3362.
Hill, S. R., K. F. Knowlton, K. M. Daniels, R. E. James, R. E. Pearson, A. V. Capuco, and R. M. Akers. 2008. Effects of milk replacer composition on growth, body composition, and nutrient excretion in preweaned Holstein heifers. J. Dairy Sci. 91:3145-3155.

Hill, T. M., H. G. Bateman, J. M. Aldrich, and R. L. Schlotterbeck. 2010. Effect of milk replacer program on digestion of nutrients in dairy calves. J. Dairy Sci. 93:1105-1115.

Hinch, G. N., E. Lecrivain, J. J. Lynch, and R. L. Elwin. 1987. Changes in maternal-young associations with increasing age of lambs Appl. Anim. Behav. Sci. 17:305-318.

Jasper, J., M. Budzynska, and D. M. Weary. 2008. Weaning distress in dairy calves: Acute behavioural responses by limit-fed calves. Appl. Anim. Behav. Sci. 110:136-143.

Jasper, J., and D. M. Weary. 2002. Effects of ad libitum milk intake on dairy calves. J. Dairy Sci. 85:3054-3058.

Jensen, M. B. 2006. Computer-controlled milk feeding of group-housed calves: The effect of milk allowance and weaning type. J. Dairy Sci. 89:201-206.

Jensen, M. B., and L. Holm. 2003. The effect of milk flow rate and milk allowance on feeding behaviour in dairy calves fed by computer controlled milk feeders . Appl. Anim. Behav. Sci. 82:87-100.

Kertz, A. F., L. R. Prewitt, and J. P. Everett Jr.. 1979. An early weaning calf program: Summarization and review. J. Dairy Sci. 62:1835-1843.

Key, C., and R. M. MacIver. 1980. The effects of maternal influences on lambs: breed-differences in grazing, resting and courtship behaviour. Appl. Anim. Ethol. 6:33-48.

Khan, M. A., H. J. Lee, W. S. Lee, H. S. Kim, K. S. Ki, T. Y. Hur, G. H. Suh, S. J. Kang, and Y. J. Choi. 2007b. Structural growth, rumen development, and metabolic and immune responses of Holstein male calves fed milk through step-down and conventional methods. J. Dairy Sci. 90:3376-3387.

Khan, M. A., H. J. Lee, W. S. Lee, H. S. Kim, S. B. Kim, K. S. Ki, J. K. Ha, H. G. Lee, and Y. J. Choi. 2007a. Pre- and postweaning performance of Holstein female calves fed milk through step-down and conventional methods. J. Dairy Sci. 90:876-885.

Khan, M. A., H. J. Lee, W. S. Lee, H. S. Kim, S. B. Kim, S. B. Park, K. S. Baek, J. K. Ha, and Y. J. Choi. 2008. Starch source evaluation in calf starter: II. Ruminal parameters, rumen development, nutrient digestibilities, and nitrogen utilization in Holstein calves. J. Dairy Sci. 91:1140-1149.

Khouri, R. H., and F. S. Pickering. 1968. Nutrition of the milk-fed calf. 1. Performance of calves fed on different levels of whole milk relative to body weight. N.Z. J. Agric. Res. 11:227-236.

Kooijman, R., E. L. Hooghe-Peters, and R. Hooghe. 1996. Prolactin, growth hormone, and insulin-like growth factor-1 in the immune system. Adv. Immunol. 63:377-454.

Krachun, C., J. Rushen, and A. M. de Passillé. 2010. Play behaviour in dairy calves is reduced by weaning and by a low energy intake. Appl. Anim. Behav. Sci. 122:71-76.

Kristensen, N. B., J. Sehested, S. K. Jensen, and M. Vestergaard 2007. Effect of milk allowance on concentrate intake, ruminal environment, and ruminal development in milk-fed Holstein calves. J. Dairy Sci. 90:4346-4355.

Kühne, S., H. M. Hammon, R. M. Bruckmaier, C. Morel, Y. Zbinden, and J. W. Blum. 2000. Growth performance, metabolic and endocrine traits, and absorptive capacity in neonatal calves fed either colostrum or milk replacer at two levels. J. Anim. Sci. 78:609-620.

Lammers, B. P., A. J. Heinrichs, and R. S. Kensinger. 1999. The effects of accelerated growth rates and estrogen implants in prepubertal Holstein heifers on estimates of mammary development and subsequent reproduction and milk production. J. Dairy Sci. 82:1753-1764

Latham, N., and G. J. Mason. 2008. Maternal separation and the development of stereotypies: A review. Appl. Anim. Behav. Sci. 110:84-108.

Lesmeister, K. E., and A. J. Heinrichs. 2004. Effects of corn processing on growth characteristics, rumen development, and rumen parameters in neonatal dairy calves. J. Dairy Sci. 87:3439-3450. 
Lidfors, L., P. Jensen, and B. Algers. 1994. Suckling in free-ranging beef cattle. Temporal patterning of suckling bouts and effects of age and sex. Ethology 98:321-332.

Maynard, L. A., and L. C. Norris. 1923. A system of rearing dairy calves with limited use of milk. J. Dairy Sci. 6:483-499.

Meyer, M. J., A. V. Capuco, D. A. Ross, L. M. Lintault, and M. E. Van Amburgh. 2006. Developmental and nutritional regulation of the prepubertal bovine mammary gland: II. Epithelial cell proliferation, parenchymal accretion rate, and allometric growth. J. Dairy Sci. 89:4298-4304.

Mirza, S. N., and F. D. Provenza. 1990. Preference of the mother affects selection and avoidance of foods by lambs differing in age. Appl. Anim. Behav. Sci. 28:255-263.

Mirza, S. N., and F. D. Provenza. 1994. Socially induced food avoidance in lambs: Direct or indirect maternal influence? J. Anim. Sci. 72:899-902.

Moallem, U., D. Werner, H. Lehrer, M. Zachut, L. Livshitz, S. Yakoby, and A. Shamay. 2010. Long-term effects of ad libitum whole milk prior to weaning and prepubertal protein supplementation on skeletal growth rate and first-lactation milk production. J. Dairy Sci. 93:2639-2650.

Mylrea, P. J. 1966. Digestion in young calves fed whole milk ad lib. and its relationship to calf scours. Res. Vet. Sci. 7:407-416.

NAHMS. 2007. Dairy 2007, part I: Reference of Dairy Cattle Health and Management Practices in the United States. Accessed July 8, 2009. http://nahms.aphis.usda.gov/dairy/dairy07/dairy2007_ highlightsPt1.pdf.

National Research Council. 2001. Nutrient Requirements of Dairy Cattle. 7th rev. ed. Natl. Acad. Sci., Washington, DC

Nielsen, P. P., M. B. Jensen, and L. Lidfors. 2008. Milk allowance and weaning method affect the use of a computer controlled milk feeder and the development of cross-sucking in dairy calves. Appl. Anim. Behav. Sci. 109:223-237.

Nolte, D. L., F. D. Provenza, and D. F. Balph. 1990. The establishment and persistence of food preferences in lambs exposed to selected foods. J. Anim. Sci. 68:998-1002.

Nonnecke, B. J., M. R. Foote, J. M. Smith, B. A. Pesch, and M. E. Van Amburgh. 2003. Composition and functional capacity of blood mononuclear leukocyte populations from neonatal calves on standard and intensified milk replacer diets. J. Dairy Sci. 86:3592-3604.

Porter, J. C., R. G. Warner, and A. F. Kertz. 2007. Effect of fiber level and physical form of starter on growth and development of dairy calves fed no forage. Prof. Anim. Sci. 23:395-400.

Quigley, J. D., T. A. Wolfe, and T. H. Elsasser. 2006. Effects of additional milk replacer feeding on calf health, growth, and selected blood metabolites in calves. J. Dairy Sci. 89:207-216.

Radcliff, R. P., M. J. Vandehaar, A. L. Skidmore, L. T. Chapin, B. R. Radke, J. W. Lloyd, E. P. Stanisiewski, and H. A. Tucker. 2000. Effects of diet and injection of bovine somatotropin on prepubertal growth and first-lactation milk yields of Holstein cows. J. Dairy Sci. 83:23-29.

Raeth-Knight, M., H. Chester-Jones, S. Hayes, J. Linn, R. Larson, D. Ziegler, B. Ziegler, and N. Broadwater. 2009. Impact of conventional or intensive milk replacer programs on Holstein heifer performance through six months of age and during first lactation. J. Dairy Sci. 92:799-809.

Reinhardt, V., and A. Reinhardt. 1981. Cohesive relationships in a cattle herd. Behaviour 77:121-151.

Roth, B. A., E. Hillmann, M. Stauffacher, and N. M. Keil. 2008. Improved weaning reduces cross-sucking and may improve weight gain in dairy calves. Appl. Anim. Behav. Sci. 111:251-261.

Roth, B. A., N. M. Keil, L. Gygax, and E. Hillmann. 2009. Influence of weaning method on health status and rumen development in dairy calves. J. Dairy Sci. 92:645-656.

Rushen, J., and A. M. de Passillé. 1995. The motivation of non-nutritive sucking in calves, Bos taurus. Anim. Behav. 49:1503-1510.

Sander, E. G., H. N. Warner, H. N. Harrison, and J. K. Loosli. 1959. The stimulatory effect of sodium butyrate and sodium propionate on the development of rumen mucosa in the young calf. J. Dairy Sci. 42:1600-1605.

Savage, E. S., and C. M. McCay. 1942. The nutrition of calves. A review. J. Dairy Sci. 25:595-650.

Sejrsen, K., S. Purup, M. Vestergaard, and J. Foldager. 2000. High body weight gain and reduced bovine mammary growth: Physiological basis and implications for milk yield potential. Domest. Anim. Endocrinol. 19:93-104.

Senn, M., S. Gross-Luem, H. Leuenberger, and W. Langhans. 2000. Meal patterns and meal-induced metabolic changes in calves fed milk ad lib. Physiol. Behav. 70:189-195.

Shamay, A., R. Homans, Y. Fuerman, I. Levin, H. Barash, N. Silanikove, and S. J. Mabjeesh. 2005. Expression of albumin in nonhepatic tissues and its synthesis by the bovine mammary gland. J. Dairy Sci. 88:569-576.

Shen, Z., H. M. Seyfert, B. Lohrke, F. Schneider, R. Zitnan, A. Chudy, S. Kuhla, H. M. Hammon, J. W. Blum, H. Martens, H. Hagemeister, and J. Viogt. 2004. An energy rich diet causes rumen papillae proliferation associated with more IGF type 1 receptors and increased plasma IGF-1 concentrations in young goats. J. Nutr. 134:11-17.

Smith, J. M., M. E. Van Amburgh, M. C. Diaz, M. C. Lucy, and D. E. Bauman. 2002. Effect of nutrient intake on the development of the somatotropic axis and its responsiveness to GH in Holstein bull calves. J. Anim. Sci. 80:1528-1537.

Soberon, F., E. Raffrenato, R. W. Everett, and M. E. Van Amburgh. 2009. Early life management and long term productivity of dairy calves. J. Dairy Sci. 92(Suppl. 1):238. (Abstr.)

Stobo, I. J. F., J. H. B. Roy, and H. J. Gaston. 1966. Rumen development in the calf. 1. The effect of diets containing different proportions of concentrates to hay on rumen development. Br. J. Nutr. 20:171-188.

Svensson, C., K. Lundborg, U. Emanuelson, and S. Olsson. 2003. Morbidity in Swedish dairy calves from birth to 90 days of age and individual calf-level risk factors for infectious diseases. Prev. Vet. Med. 58:179-197.

Sweeney, B. C., J. P. Rushen, D. M. Weary, and A. M. B. de Passillé. 2010. Duration of weaning, starter intake, and weight gain of dairy calves fed large amounts of milk. J. Dairy Sci. 93:148-152.

Tamate, H., A. D. McGilliard, N. L. Jacobson, and R. Getty. 1962 Effect of various dietaries on the anatomical development of the stomach in the calf. J. Dairy Sci. 45:408-420.

Terré, M., M. Devant, and A. Bach. 2007. Effect of level of milk replacer fed to Holstein calves on performance during the preweaning period and starter digestibility at weaning. Livest. Sci. 110:82-88.

Thomas, T. J., D. M. Weary, and M. C. Appleby. 2001. Newborn and 5 -week-old calves vocalise in response to milk deprivation. Appl. Anim. Behav. Sci. 74:165-173.

Tikofsky, J. N., M. E. Van Amburgh, and D. A. Ross. 2001. Effect of varying carbohydrate and fat content of milk replacer on body composition of calves. J. Anim. Sci. 79:2260-2267.

von Keyserlingk, M. A. G., J. Rushen, A. M. B. de Passillé, and D. M. Weary. 2009. Invited review: The welfare of dairy cattle-Key concepts and the role of science. J. Dairy Sci. 92:4101-4111.

von Keyserlingk, M. A. G., and D. M. Weary. 2007. Maternal behavior in cattle: A review. Horm. Behav. 52:106-113.

Warner, R. G., W. P. Flatt, and J. K. Loosli. 1956. Dietary factors influencing the development of the animal's stomach. J. Agric. Food Chem. 4:788-792.

Weary, D. M., J. M. Huzzey, and M. A. G. von Keyserlingk. 2009. Board-invited review: Using behavior to predict and identify ill health in animals. J. Anim. Sci. 87:770-777.

Weary, D. M., J. Jasper, and M. J. Hötzel. 2008. Understanding weaning distress. Appl. Anim. Behav. Sci. 110:24-41.

Williams, P. E. V., and A. J. Frost. 1992. Feeding the young ruminant. Pages 109-118 in Neonatal Survival and Growth. Occasional Publ. No. 15. M. Varley, P. E. V. Williams, and T. L. J. Lawrence, ed. Br. Soc. Anim. Prod., Edinburgh, UK. 